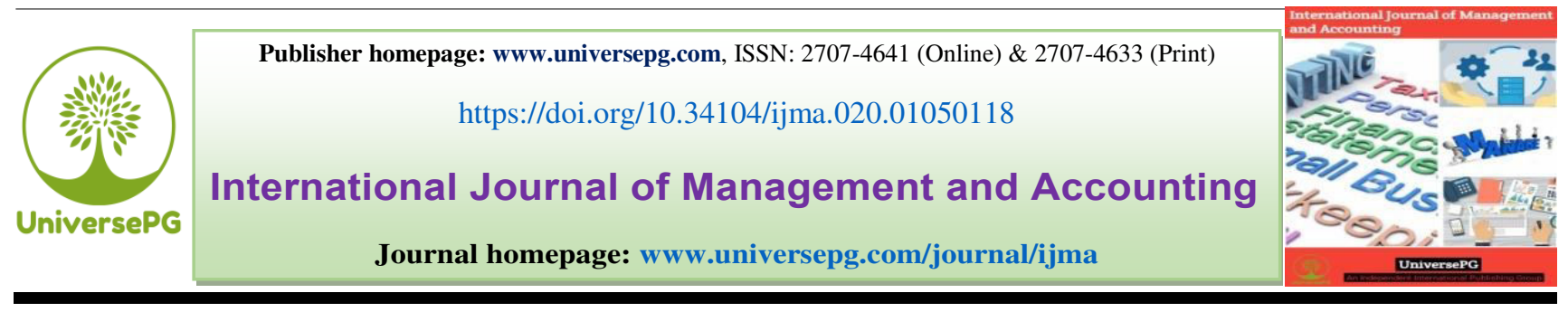

\title{
Women Employment Opportunity on SMEs Sector: Bangladesh Perspective
}

\author{
Sharifa Akter* \\ Department of Human Resource Management, Jatiya Kabi Kazi Nazrul Islam University (JKKNIU), Trishal, \\ Mymensingh, Bangladesh. \\ *Correspondence: sharifahrm13@gmail.com (Sharifa Akter, Lecturer, Department of Human Resource Management, \\ JKKNIU, Trishal, Mymensingh).
}

\begin{abstract}
This study explores women's work prospects in the SME sector of Bangladesh. The researcher has identified two different reasons to conduct this study separately. Number one is that in the last few decades, have played a very active and important role, and the second is that by empowering women, female entrepreneurs build new job opportunities and solve the different problems of society. Small and mediumsized enterprises, which play an important role as engines of economic growth in many countries, provide growth opportunities for low-cost jobs. The results of the study illustrate the correlation between job opportunities for SMEs and women. Women's entrepreneurship is seen as a crucial instrument of women's empowerment and emancipation. Small and medium-sized enterprises, which play an important role in many countries as engines of economic growth, provide opportunities for low-cost employment with growth. The study finding shows the relationship between employment opportunities for SMEs and Women. Women entrepreneurship is seen as a key tool for empowering and liberating women. Developing countries such as Bangladesh are better off starting a small and medium-sized company because Bangladesh belongs to the low-income group facing problems of unemployment, poverty, low savings rate, low capital accumulation. Business on the micro and small scale did not require huge investment, it begins with limited capital. Developing nations such as Bangladesh are better off starting a small and medium-sized business because Bangladesh is part of the low-income community facing unemployment, poverty, low savings rate, low accumulation of capital problems. Micro and small-scale companies did not need tremendous investment but began with minimal resources.
\end{abstract}

Keywords: Women employment, Entrepreneurs, Bangladesh, Opportunity, Perspective, and SMEs.

\section{INTRODUCTION:}

In both Bangladesh's urban and rural areas, SME women entrepreneurs have emerged as a new class. Bangladesh is, in reality, considered to be a very recent phenomenon of entrepreneurial women or women in industry. While women are committed to entrepreneurship in many difficult fields, their operations in Bangladesh are not very large (Ahammad, 2013; Zaman, 2013). Women have succeeded in industry, despite fewer resources, but they are still limited in number. In the recent past, an

UniversePG I www.universepg.com unprecedented rising interest in women's entrepreneurship in small businesses has been observed in Bangladesh (Bosri, 2016). It is widely recognized that SMEs play an important role in job generation, poverty reduction and overall economic developpment, especially for a developing economy such as Bangladesh. SMEs are usually sectors of relatively low capital intensity that are labor-intensive. As such, for a country like Bangladesh, which is labor abundant and capital scarce, SMEs have a natural comparative advantage and creates opportunity for women (Chowdhury et al., 2015). 
SMEs currently possess a significant situation in the public economy. They represent around 45 percent of assembling esteem expansion, around $80 \%$ of mechanical work, around $90 \%$ of all out modern units and around 25 percent of the workforce. Their complete commitment to trade income differs from 75 percent to 80 percent (Basu et al., 2020). The modern area makes up 31 percent of the nation's (GDP), the vast majority of which is originating from SMEs. The complete number of SMEs in Bangladesh is assessed to be 79,754 foundations. Of them, 93.6 percent are little and 6.4 percent are medium (Rashid and Islam, 2020). The nation's SME area has made 15 lakh occupations among 2009 and June 2014. Presently, private and unfamiliar banks dispense half of all homestead advances and 33\% of these are going to SMEs (Khatun and Kabir, 2013).

This paper makes an endeavor to feature the chance of women work in little and medium ventures (SME). Furthermore, this paper likewise develops the regions, issues, issues which work behind the women employability and furthermore give potential answers for defeat the issues which will help in expanding the odds of chance of women work in SME in Bangladesh.

\section{Literature Review}

Rahman and Mahmood (2007) specify that Small and Medium Enterprises are the foundation of the economy in nations like Bangladesh. SMEs experience the ill effects of basic imperatives, for example, absence of capital, troubles in getting crude materials, absence of admittance to significant business data, low mechanical capacities, issues brought about by lumbering and exorbitant regulatory strategies, and arrangements and guidelines that create market moving. In any case, with legitimate homegrown approach uphold from the administration, and an eye towards worldwide market patterns, SMEs can construct limit and receive the benefits of globalization.

Al-Hossienie (2011) completed an investigation on financial effect of lady enterprise in Sylhet city, Bangladesh. He spoke to in the paper that zeroed in on investigating the financial effect of women business in the concerned region. In view of essential and optional sources, it is discovered that almost seventy five percent of the women business visionaries in Sylhet city are hitched and that they are mostly associated with fitting and salon organizations. About portion of the women business visionaries utilize their salary for family purposes and the majority of them needn't bother with consent of their spouses in utilizing their pay (Islam, 2020). Women business enterprise ordinarily acquires a positive change mentality and conduct of relatives and society towards them. This paper additionally gives a few suggestions to strategy producers to attempt reasonable and compelling approaches towards the advancement of women business in the zone.

Ahmed, (2004) brings up that because of the absence of public quality approach and sufficient emotionally supportive network, and furthermore the absence of validity of the quality accreditation authority, SMEs of Bangladesh have neglected to guarantee the nature of items and administrations both in homegrown and worldwide business sectors. He likewise contends that admittance to back wins as one of the most significant issues for the SMEs in Bangladesh. Absence of contributing or working supports stays as one of the most unmistakable whines of practically all the SME in Bangladesh.

Rabbani and Sulaiman, (2005) saw that the 50.53 percent of SMEs had no admittance to formal wellspring of fund. Just 35.79 percent of SMEs appreciate unhindered admittance to the conventional credit. Of the rest 13.68 percent have limited admittance to formal credit. Bank credit is utilized by little level of business people and gives financing of commonly fewer than $20 \%$ of their complete expense. Larger part of the SMEs (59.6 percent) looks for money for their working capital needs from banks, albeit just a portion of them get credit from banks.

Hasan and Islam (2008) recognized that banks ordinarily don't communicate enthusiasm towards SME financing. The explanation for this conservativeness is higher operational cost, less return and high danger related with the SME financing. Because of little advance size the operational expense is higher and they require concentrated observing and oversight. The principle explanation behind higher danger is that the little and medium business people are profoundly improbable to consent to the insurance necessities as normally they don't have unfaltering properties. With the reason of insurance at times banks and non-bank money 
related establishments are hesitant to back SMEs. Sultana A. (2012) in her diary distinguished some business issues and some social issues looked by women which fill in as hindrances toward women work opportunity in Bangladesh.

\section{Objectives of the Study}

The primary objective of this study is to maintain the women's job opportunity scenario in Bangladesh's SME market.

Specific objective: This study's specific objective is-

- To investigate the regions of work chance of women in SME.

- To look at the effect of their business fair and square of pay, expectation for everyday comforts and the prosperity of their relatives.

- To discover the variables and impact of the improvement of women business enterprise in SME.

- To recognize the components those debilitate or make obstructions in women work in SME.

- To discover the approaches to beat the obstructions of women enterprise in SME in Bangladesh.

\section{METHODOLOGY:}

In this analysis, information is collected and analyzed using both qualitative and quantitative data.
Data were collected from primary sources as well as secondary sources (Bangladesh Bank, 2008), newspapers and newspapers as well. Several methodologies are used in this study to gather data from both primary and secondary sources. Here, $50 \mathrm{SME}$ women entrepreneurs are chosen as a sample.

The questionnaires were built in the style of Likert, and the data gathered through the questionnaire and face-to - face interaction are shown in the graph. All of the information was evaluated on the basis of the respondent's response.

\section{ANALYSIS AND RESULTS:}

There are many sectors in SME Business. The respondents who run SME business at different sectors have given their responses about the interest level on which sectors they must prefer to run the business. Where it has been seen that $32 \%$ respondents prefer Handicrafts business where as Garments home textiles is preferred by $16 \%$ respondents. $20 \%$ respondents feel better to conduct their business in Agro based business and also Food and Parlor business respectively chosen by $10 \%$ and $22 \%$ of total respondent (Table 1 and Fig 1). This chart shown that maximum respondent choose Handicraft business in contrast of others business where Food sector is chosen by lowest number of respondent.

Table 1: Types of business operated by women

\begin{tabular}{|c|c|c|c|c|c|c|c|}
\hline & \multicolumn{6}{|c|}{ Description of Respondents } & \multirow{2}{*}{ 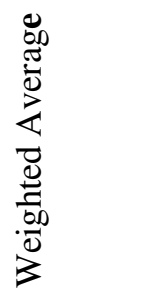 } \\
\hline & 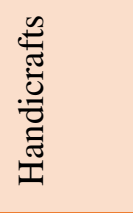 & 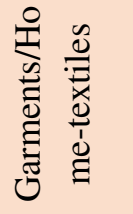 & 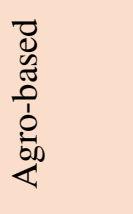 & $\begin{array}{l}\overline{0} \\
8 \\
\end{array}$ & $\frac{\overrightarrow{0}}{\bar{\pi}}$ & 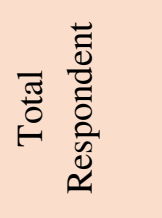 & \\
\hline Number & 16 & 8 & 10 & 5 & 11 & 50 & 3.26 \\
\hline Percentage & $32.0 \%$ & $16.0 \%$ & $20.0 \%$ & $10.0 \%$ & $22.0 \%$ & $100.0 \%$ & \\
\hline
\end{tabular}

Table 2: Needed motivation From Family Members

\begin{tabular}{|c|c|c|c|c|c|c|c|}
\hline & \multicolumn{6}{|c|}{ Description of Respondents } & \multirow{2}{*}{ 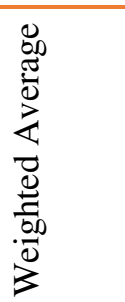 } \\
\hline & 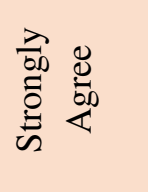 & 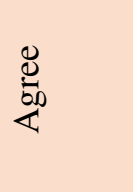 & 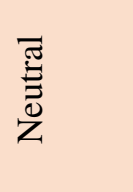 & 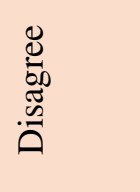 & 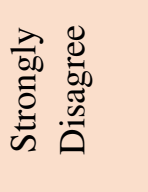 & 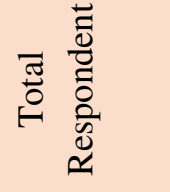 & \\
\hline Number & 20 & 15 & 10 & 5 & 0 & 50 & 4.3 \\
\hline Percentage & $40.0 \%$ & $30.0 \%$ & $20.0 \%$ & $10.0 \%$ & $0.0 \%$ & $100.0 \%$ & \\
\hline
\end{tabular}




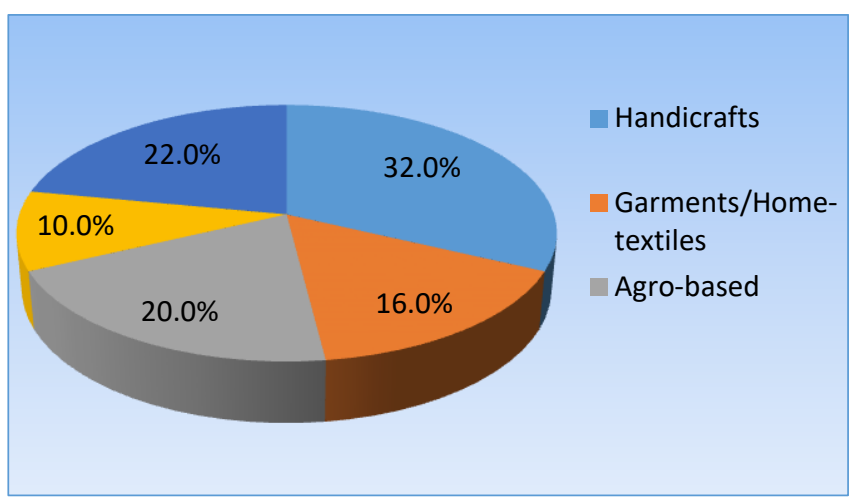

Fig 1: Types of business operated by women.

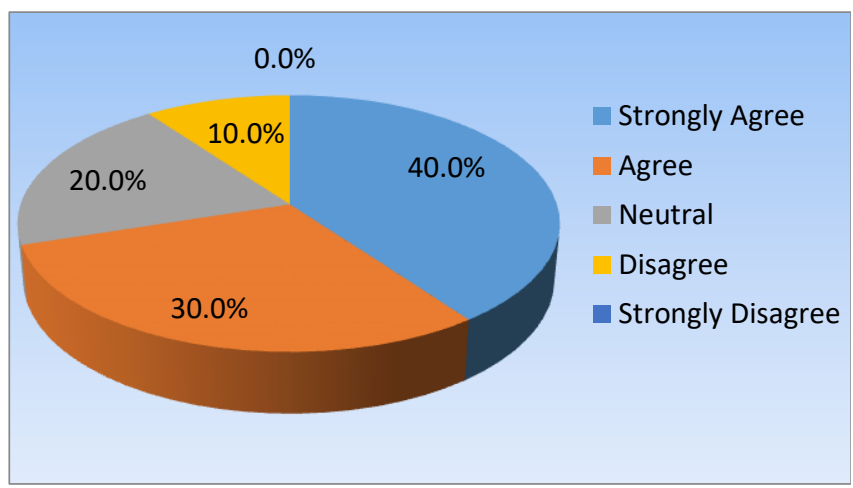

Fig 2: Needed motivation from family members.

It has been said that motivation in every sectors of life work as like as magic. So it is needed to run the task smoothly specially to women (Yasmin and Husna, 2020). So in our survey it is seen that most of the respondents opine that motivation, inspi- ration is very much crucial to conduct any task especially in case of women entrepreneur $(40 \%$ respondent). $30 \%$ of total respondents normally agree that it is necessary to run business where $20 \%$ give no comments. $10 \%$ respondents disagree and think that motivation cannot work without other supportive device (Table 2 and Fig 2).

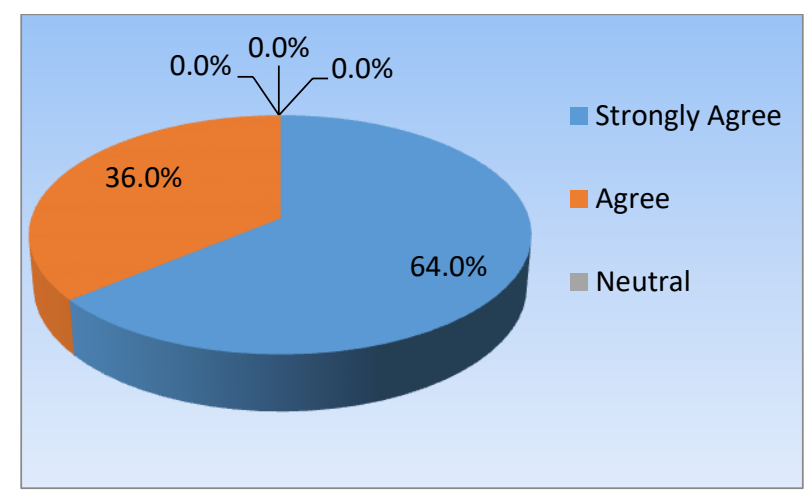

Fig 3: Support in Family wellbeing.

The respondents feel better when they can realize that they are also a member who contributes in family wellbeing. Here in our survey $54 \%$ respondents strongly agree that they are a supportive member of family wellbeing and also $36 \%$ respondents normally agree with this matter (Table 3 and Fig 3). In our society when women get motivation then they get inspiration to do something and when they can contribute in family wellbeing then they feel better also.

Table 3: Support in family wellbeing

\begin{tabular}{|c|c|c|c|c|c|c|c|}
\hline & \multicolumn{6}{|c|}{ Description of Respondents } & \multirow{2}{*}{ 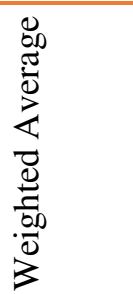 } \\
\hline & 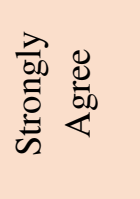 & $\begin{array}{l}\stackrel{8}{0} \\
\stackrel{5}{4}\end{array}$ & $\begin{array}{l}\bar{\pi} \\
\overline{0} \\
\bar{Z}\end{array}$ & 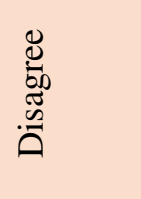 & 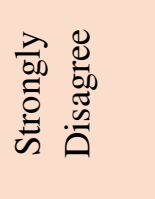 & 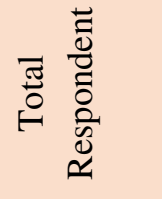 & \\
\hline Number & 32 & 18 & 0 & 0 & 0 & 50 & 4.64 \\
\hline Percentage & $64.0 \%$ & $36.0 \%$ & $0.0 \%$ & $0.0 \%$ & $0.0 \%$ & $100.0 \%$ & \\
\hline
\end{tabular}

Table 4: Change of life style

\begin{tabular}{|c|c|c|c|c|c|c|c|}
\hline & \multicolumn{6}{|c|}{ Description of Respondents } & \multirow{2}{*}{ 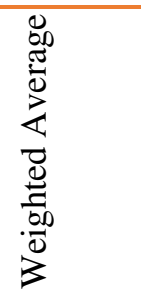 } \\
\hline & 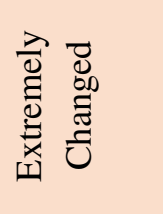 & $\begin{array}{l}\vec{D} \\
\infty \\
\bar{\Xi} \\
\bar{U}\end{array}$ & $\begin{array}{l}\bar{\Xi} \\
\overline{0} \\
\bar{z}\end{array}$ & 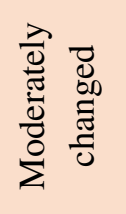 & 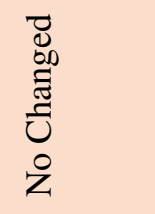 & 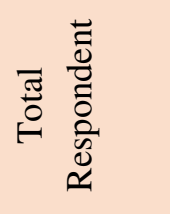 & \\
\hline Number & 22 & 18 & 10 & 0 & 0 & 50 & 4.24 \\
\hline Percentage & $44.0 \%$ & $36.0 \%$ & $20.0 \%$ & $0.0 \%$ & $0.0 \%$ & $100.0 \%$ & \\
\hline
\end{tabular}




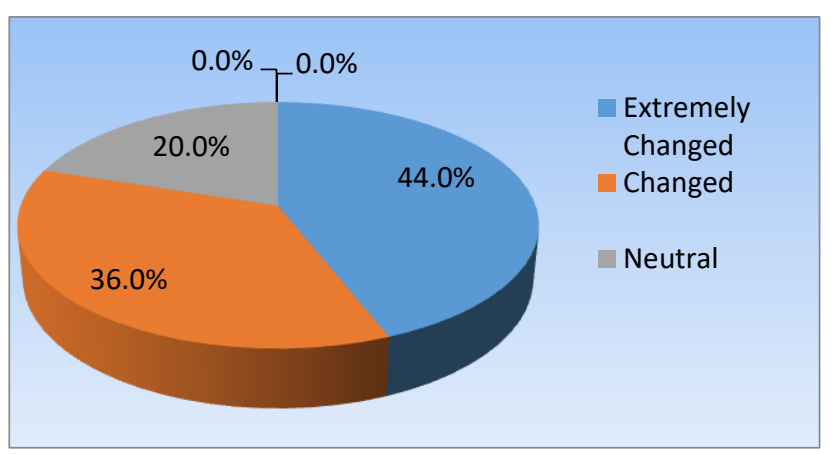

Fig 4: Change of Life style.

Every man and woman have own life style in home, there is a change in life style of every man and woman with the improvement of their profession. Women who engaged in SME business extremely notice about the change of their daily life. Maximum respondent argues that (44\%) due to their business activities there have been tremendous change in their life. Someone ( $36 \%$ of respondents) opine that their life style have been changed due to engaged in business. On the other hand 20\% respondent remains neutral to express their opinion (Table 4 and Fig 4). No respondents mention that there is unchangeable life style due to engage in business activities. Women entrepreneur as they engaged in business have always try to balance with family and business activities.

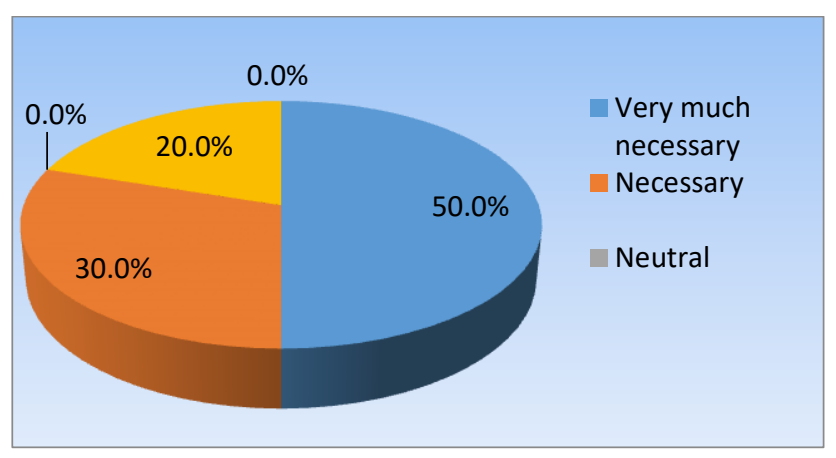

Fig 5: Trade license is necessary.

Trade license is permission granted in form of certificate by state government to carry on any business for which it is issued.

Table 5: Trade license is necessary
As per shops and establishment Act it is mamdatory for three kinds of business: (1). All the eating establishments like hotels, restrurents, food stall, bakeries, provisions store, etc; (2). Trades which use motives like manufacturing industries, factories, powerlooms, cyber café, flour mill etc; (3). Offensive and dangerous trades like barber shop, dhopi shop, candle manufacture et On the basis of our survey maximum of our respondents (50 respondents) think that trade license is very much necessary to carry out the business. On the other hand $30 \%$ respondents opine it is necessary, $0 \%$ neutral and $20 \%$ respondents thinks it is moderately necessary. Where as there is no one $(0 \%)$ who thik it is unnecessary (Table 5 and Fig 5).

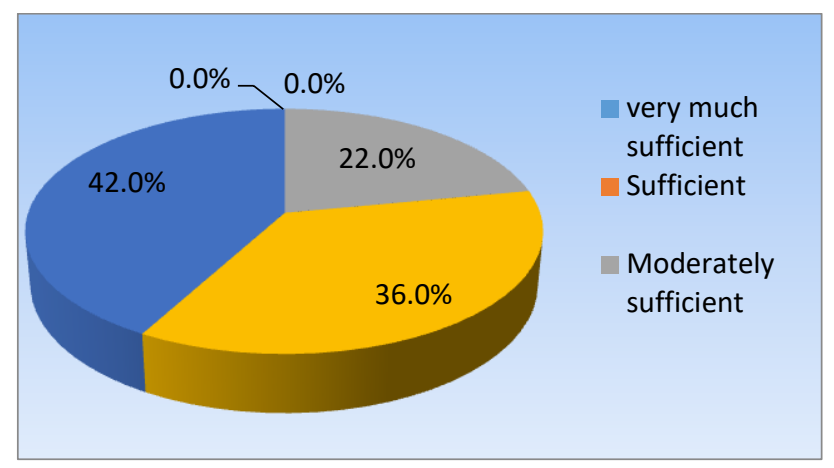

Fig 6: Source of own capital.

The core element of business enterprise is capital. Without sufficient capital business can not run smoothly. In Bangladesh most of women business owner suffer for business capital. Women entrepreneur faces lots of problems to collect capital that hampers their planned busines. On our survey it is find out that most of the respondent ( $42 \%$ of total) argues about their totally insufficient sources of capital. From the $36 \%$ respondents opinion it is noticed that sources of capital is insufficient. Where as only $22 \%$ respondents opine that they have moderately sufficient sources of own capital. In this survey it is seen that there is no one respondents $(0 \%)$ have sufficient source of capital (Table 6 and Fig 6).

\begin{tabular}{|c|c|c|c|c|c|c|c|}
\hline & \multicolumn{6}{|c|}{ Description of Respondents } & \multirow[b]{2}{*}{ 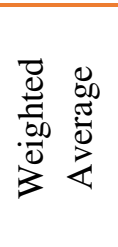 } \\
\hline & 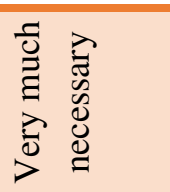 & $\begin{array}{l}\text { त्र } \\
\tilde{\omega} \\
\tilde{U} \\
\ddot{z}\end{array}$ & $\begin{array}{l}\bar{\pi} \\
\stackrel{\Xi}{0} \\
\bar{Z}\end{array}$ & 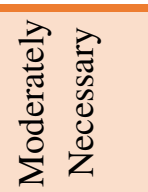 & 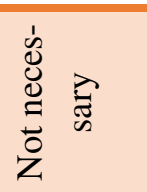 & 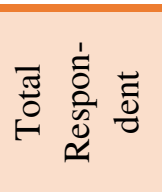 & \\
\hline Number & 25 & 15 & 0 & 10 & 0 & 50 & 4.2 \\
\hline Percentage & $50.0 \%$ & $30.0 \%$ & $0.0 \%$ & $20.0 \%$ & $0.0 \%$ & $100.0 \%$ & \\
\hline
\end{tabular}


Table 6: Source of own capital

\begin{tabular}{|c|c|c|c|c|c|c|c|}
\hline & \multicolumn{6}{|c|}{ Description of Respondents } & \multirow{2}{*}{ 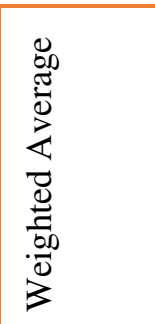 } \\
\hline & 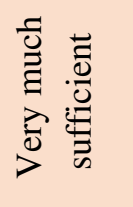 & 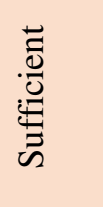 & 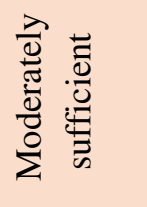 & 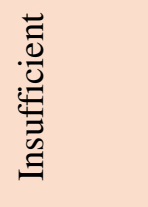 & 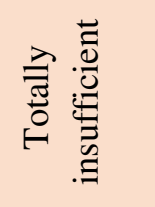 & 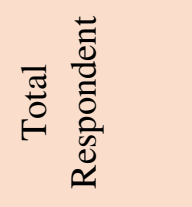 & \\
\hline Number & 0 & 0 & 11 & 18 & 21 & 50 & 1.8 \\
\hline Percentage & $0.0 \%$ & $0.0 \%$ & $22.0 \%$ & $36.0 \%$ & $42.0 \%$ & $100.0 \%$ & \\
\hline
\end{tabular}

Table 7: Getting loans is easy

\begin{tabular}{|c|c|c|c|c|c|c|c|}
\hline & \multicolumn{6}{|c|}{ Description of Respondents } & \multirow[b]{2}{*}{ 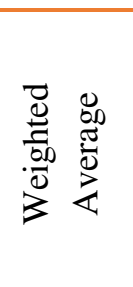 } \\
\hline & 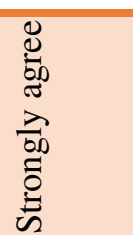 & 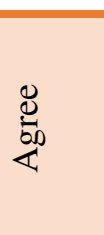 & $\begin{array}{l}\bar{\pi} \\
\bar{\Xi} \\
\bar{Z}\end{array}$ & 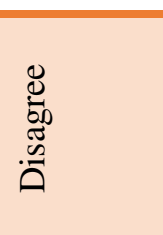 & 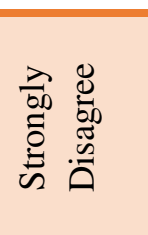 & 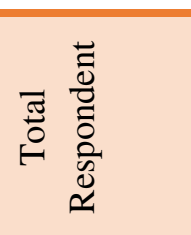 & \\
\hline Number & 0 & 0 & 10 & 17 & 23 & 50 & 1.74 \\
\hline Percentage & $0.0 \%$ & $0.0 \%$ & $20.0 \%$ & $34.0 \%$ & $46.0 \%$ & $1000 \%$ & \\
\hline
\end{tabular}

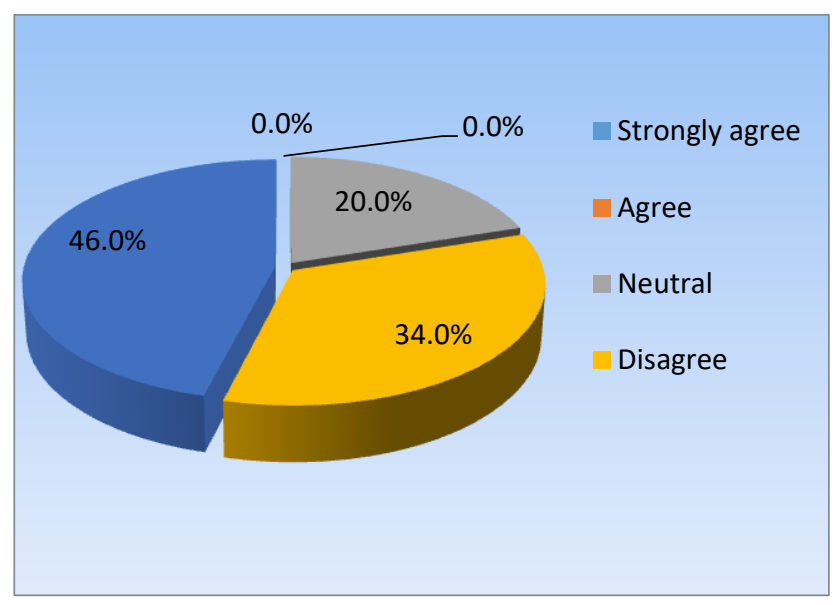

Fig 7: Getting loans is easy.

A loan facility for meeting regular as well as additional requirements of business, it is also the part of working capital of the business. In our survey most of the respondents (46\% of total) opine that getting loan is not so easy. They have to meet up requirement of financial institutions that is very much conditional.

$34 \%$ respondent disagrees with the easy getting of loan because they suffer when they want to get loan from financial institutions. Whereas $20 \%$ of total respondents remain neutral to comment on getting loan is easy (Table 7 and Fig 7).

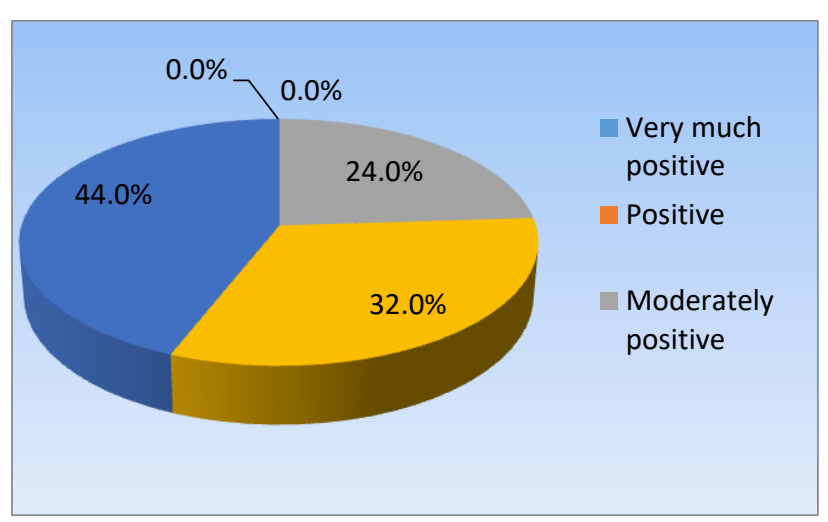

Fig 8: Environmental Support.

Environmental support includes effort or programs that provide opportunities or decrease obstacles for making healthy decisions within the work environment. Many businesses have realized that going beyond environmental compliance makes good business sense and can help improve our long term success. From our survey it is found that women entrepreneurs basically fell unsafe from environmental protection $44 \%$ respondents think that environmental support for women entrepreneur very much negative and $32 \%$ of total respondents argues negative where as $24 \%$ feel that there is moderately positive environmental support in SME sector for women (Table 8 and Fig 9). 


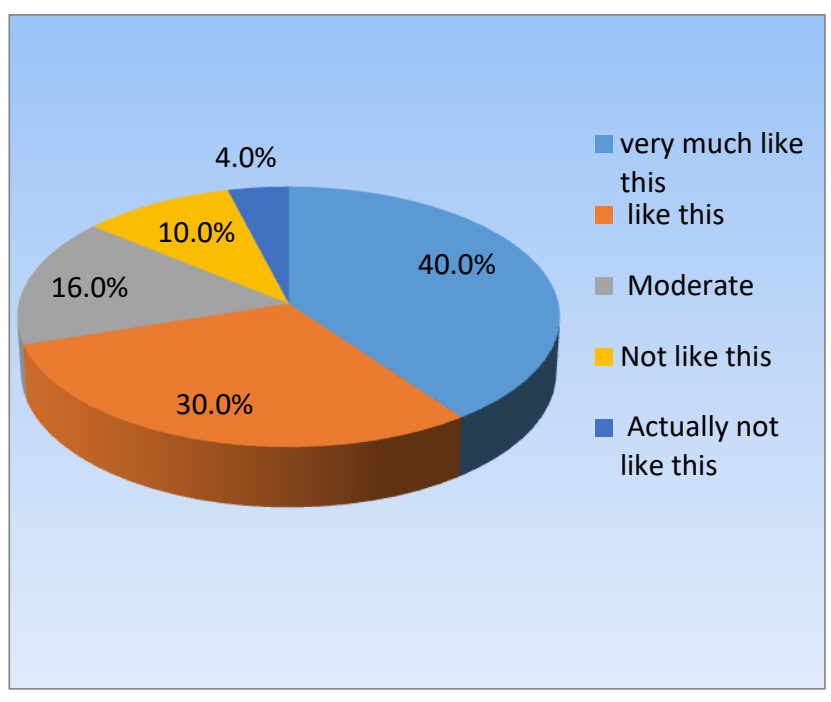

Fig 9: Enter into business because of not having a job.
Bangladesh has vast population with huge amount of unemployed youth. Day by day unemployement problem increasing at a alarming rate. Every year thousand and thousand of students come out from university with graduation but there is no opportunities for employment at such rate. For this reason most of the graduates intent to business for changing their life.

In our survey $40 \%$ of respondents very much agree that they engaged in business as there is not enough job opportunity in our country and also $30 \%$ of total respondents opine like this, $16 \%$ think that moderately like where as $10 \%$ opine that not like this and $4 \%$ argues actually not like this (Table 9 and Fig 9).

Table 8: Environmental support.

\begin{tabular}{|c|c|c|c|c|c|c|c|}
\hline & \multicolumn{6}{|c|}{ Description of Respondents } & \multirow[b]{2}{*}{ 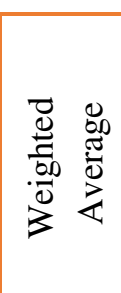 } \\
\hline & 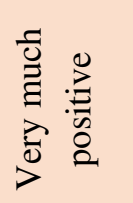 & $\begin{array}{l}\stackrel{0}{\Xi} \\
\stackrel{0}{0} \\
\stackrel{0}{0}\end{array}$ & 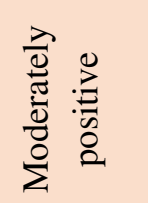 & 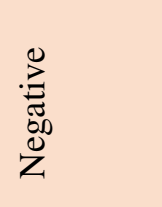 & 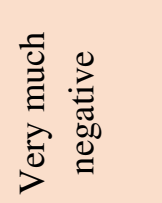 & 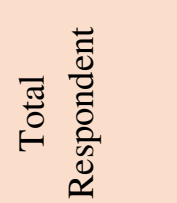 & \\
\hline Number & 0 & 0 & 12 & 16 & 22 & 50 & 1.8 \\
\hline Percentage & $0.0 \%$ & $0.0 \%$ & $24.0 \%$ & $32.0 \%$ & $44.0 \%$ & $100.0 \%$ & \\
\hline
\end{tabular}

Table 9: Enter into business because of not having a job

\begin{tabular}{|c|c|c|c|c|c|c|c|}
\hline & \multicolumn{6}{|c|}{ Description of Respondents } & \multirow[b]{2}{*}{ 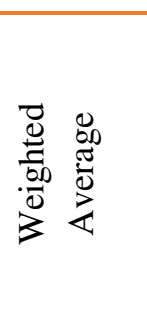 } \\
\hline & 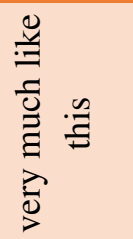 & 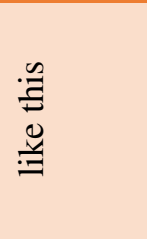 & $\begin{array}{l}\frac{\pi}{\pi} \\
\frac{\pi}{0} \\
\sum\end{array}$ & $\begin{array}{l}\stackrel{y}{\Xi} \\
\vdots \\
0 \\
\vdots \\
\vdots \\
0 \\
z\end{array}$ & 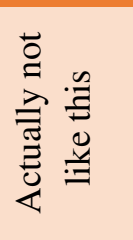 & 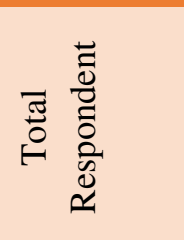 & \\
\hline Number & 20 & 15 & 8 & 5 & 2 & 50 & 3.92 \\
\hline Percentage & $40.0 \%$ & $30.0 \%$ & $16.0 \%$ & $10.0 \%$ & $4.0 \%$ & $100.0 \%$ & \\
\hline
\end{tabular}

Table 10: High interest rate

\begin{tabular}{|c|c|c|c|c|c|c|c|}
\hline & \multicolumn{6}{|c|}{ Description of Respondents } & \multirow[b]{2}{*}{ 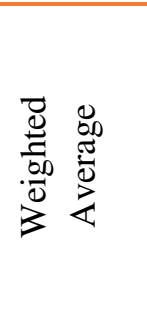 } \\
\hline & 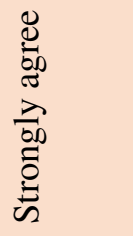 & $\begin{array}{l}\stackrel{D}{0} \\
\stackrel{5}{\ll}\end{array}$ & $\begin{array}{l}\bar{\pi} \\
\stackrel{\Xi}{0} \\
\stackrel{0}{Z}\end{array}$ & 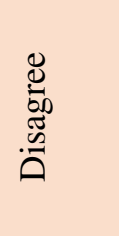 & 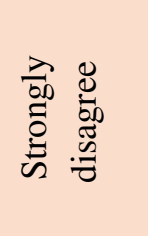 & 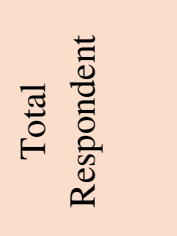 & \\
\hline Number & 28 & 22 & 0 & 0 & 0 & 50 & 4.56 \\
\hline Percentage & $56.0 \%$ & $44.0 \%$ & $0.0 \%$ & $0.0 \%$ & $0.0 \%$ & $100.0 \%$ & \\
\hline
\end{tabular}




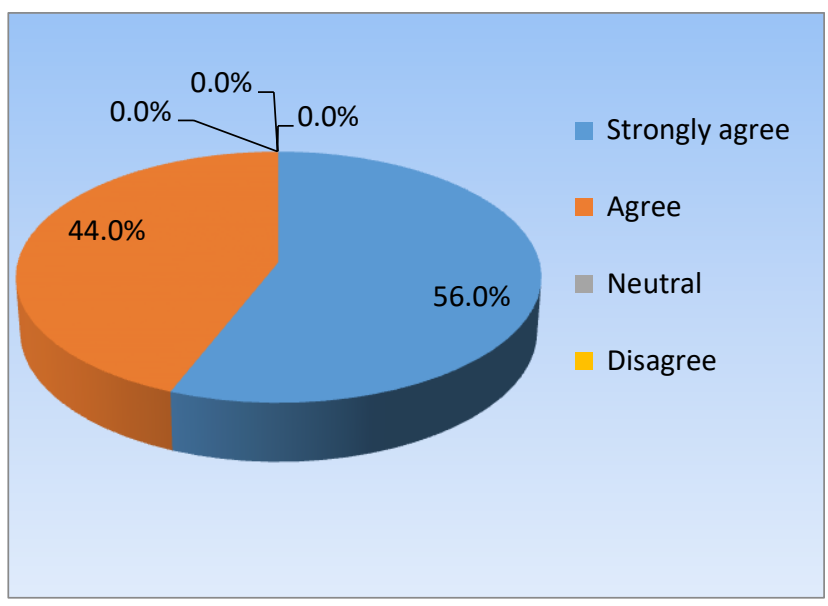

Fig 10: High interest rate.

Bangladesh bank announced that all the bank in our country have to decrease their interest rate in one digit but still now this instruction is not implemented by the bank. For this reason all the business fall in trouble to collect loan from financial institutions (Financial Express, 2020). Most of our respondents (56\% of total) very much agree that interest rate is very high that hampers our business activities and the rest of $44 \%$ respondents also agree with this comment (Table 10 and Fig 10). Whereas it is seen that there is no one who opine about interest is affordable.

Table 11: Hindrance of marketing products

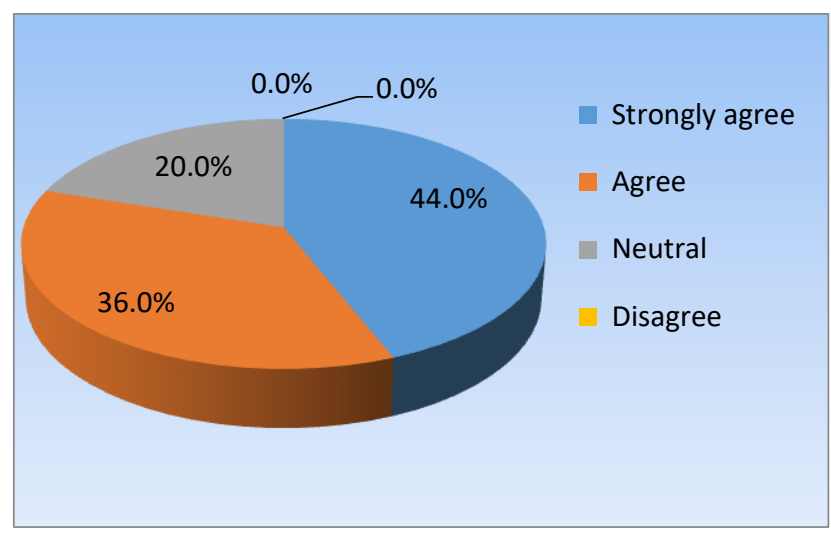

Fig 11: Hindrance of marketing products.

Properly marketing of products can help to get success in business. Women entrepreneur who get engaged in SME business regularly face problems on their product marketing. Most of the women entrepreneur opine that there is no smooth environment where they can easily establish a sound market for their products.women entrepreneur faces a bunches of problems in every step of their product marketing. So $44 \%$ of total respondents strongly agree with hindrance of product marketing, $36 \%$ of total is normally agree and rest of $20 \%$ respondent remains neutral to comment on it. But there is no one $(0 \%)$ who disagree or strongly disagree on it (Table 11 and Fig 11).

\begin{tabular}{|c|c|c|c|c|c|c|c|}
\hline & \multicolumn{6}{|c|}{ Description of Respondents } & \multirow{2}{*}{ 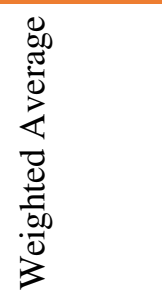 } \\
\hline & 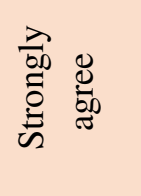 & 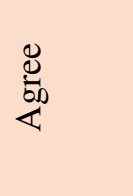 & $\begin{array}{l}\bar{\pi} \\
\overline{0} \\
\bar{Z}\end{array}$ & 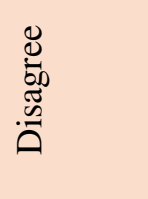 & 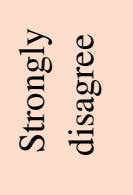 & 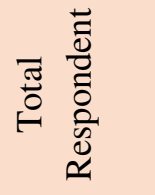 & \\
\hline Number & 22 & 18 & 10 & 0 & 0 & 50 & 4.24 \\
\hline Percentage & $44.0 \%$ & $36.0 \%$ & $20.0 \%$ & $0.0 \%$ & $0.0 \%$ & $100.0 \%$ & \\
\hline
\end{tabular}

Table 12: Pre-knowledge is necessary

\begin{tabular}{|c|c|c|c|c|c|c|c|}
\hline & \multicolumn{6}{|c|}{ Description of Respondents } & \multirow[b]{2}{*}{ 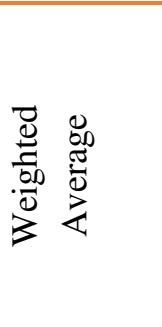 } \\
\hline & $\begin{array}{l}\overline{0} \\
\vec{\Xi} \\
\vec{\Xi} \\
\overrightarrow{0} \\
\overrightarrow{0} \\
\overrightarrow{0} \\
>\end{array}$ & 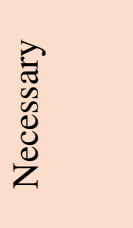 & 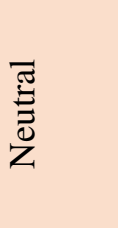 & 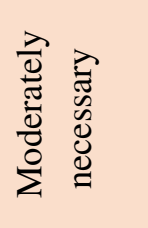 & 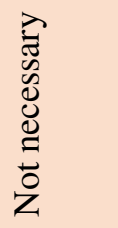 & 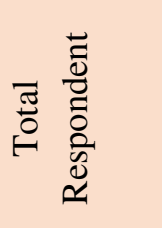 & \\
\hline Number & 19 & 15 & 0 & 16 & 0 & 50 & 3.74 \\
\hline Percentage & $38.0 \%$ & $30.0 \%$ & $0.0 \%$ & $32.0 \%$ & $0.0 \%$ & $100.0 \%$ & \\
\hline
\end{tabular}




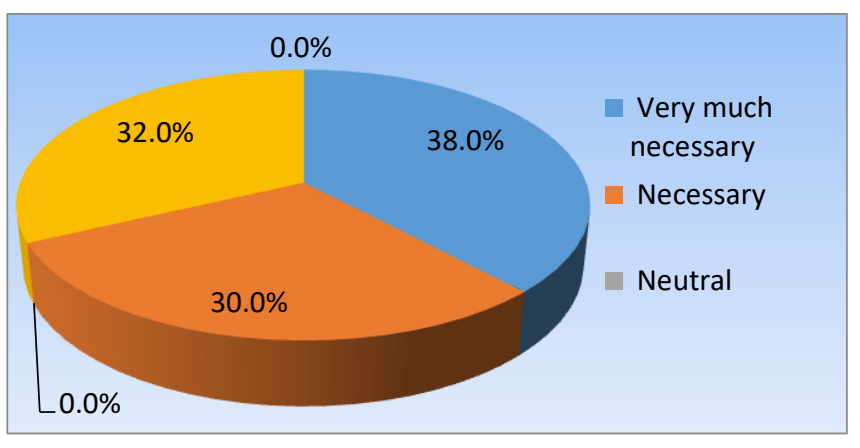

Fig 12: Pre-knowledge is necessary.

Every task will be easy when enough knowledge about this task available within the women entrepreneur.In bangladesh most of the women entrepreneur have no enough pre-knowledge about the desired business activities.From our survey maximium respondent $(38 \%$ of total) very much agree and 30\% agree that preknowledge must needed for starting the SME business where as $32 \%$ respondent think that pre-knowledge is moderately necessary to start the business (Table $\mathbf{1 2}$ and Fig 12).

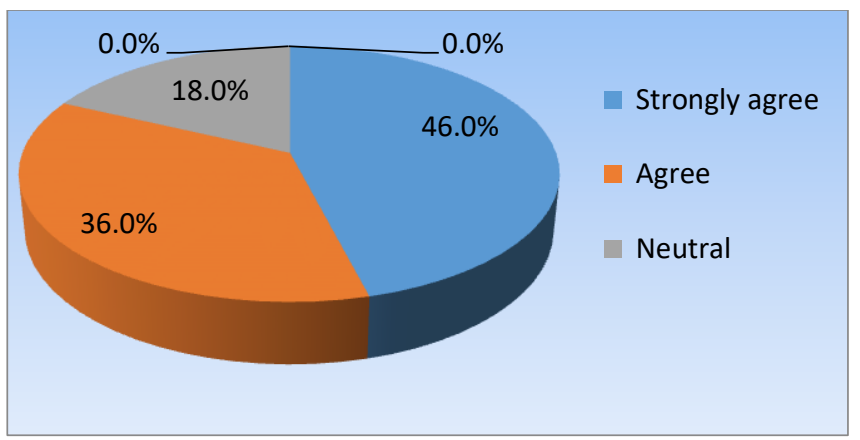

Training is teaching or developing in oneself or others any skill and knowledge of fitness that relate tp specific usefull competencies.Inour survey $46 \%$ of respondents strongly agree and $36 \%$ of total agree that training is very much needed to operate business smoothly where as 18\% respondemts re,main neutral to opine (Table 13 and Fig 13).

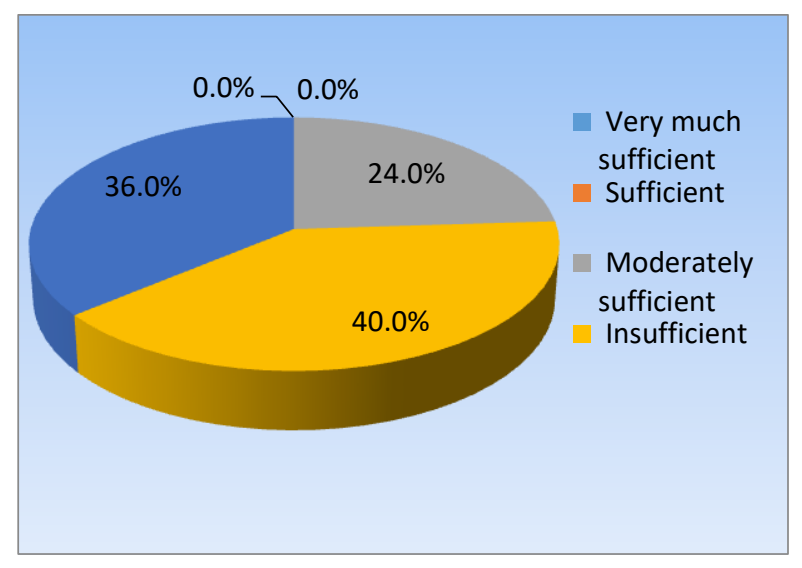

Fig 14: Sufficient Govt. help.

Besides private investment Govt. help also can make easy to operate business function.In our survey $40 \%$ respondents opine that Govt. help is insufficient and $36 \%$ think that it is totally insufficient whereas $24 \%$ argues about this moderately sufficient (Table 14 and Fig 14). there is no one respondent who think that Govt. help is sufficient for SME business.

Fig 13: Need of training.

Table 13: Need of training

\begin{tabular}{|c|c|c|c|c|c|c|c|}
\hline & \multicolumn{6}{|c|}{ Description of Respondents } & \multirow[b]{2}{*}{ 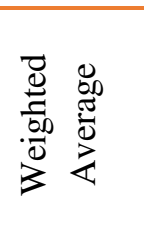 } \\
\hline & 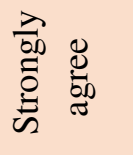 & $\begin{array}{l}\frac{8}{0} \\
\stackrel{5}{*}\end{array}$ & $\begin{array}{l}\bar{\Xi} \\
\overline{0} \\
\bar{z}\end{array}$ & 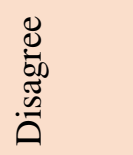 & 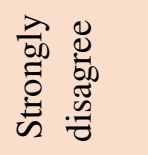 & 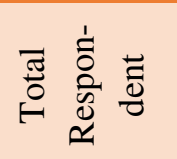 & \\
\hline Number & 23 & 18 & 9 & 0 & 0 & 50 & 4.24 \\
\hline Percentage & $46.0 \%$ & $36.0 \%$ & $18.0 \%$ & $0.0 \%$ & $0.0 \%$ & $100.0 \%$ & \\
\hline
\end{tabular}

Table 14: Sufficient Govt. help

\begin{tabular}{|c|c|c|c|c|c|c|c|}
\hline & \multicolumn{6}{|c|}{ Description of Respondents } & \multirow[b]{2}{*}{ 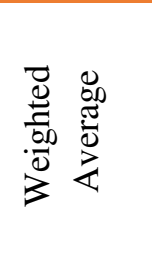 } \\
\hline & 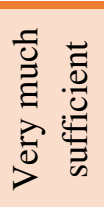 & 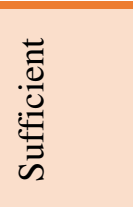 & 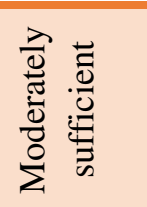 & 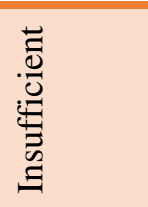 & 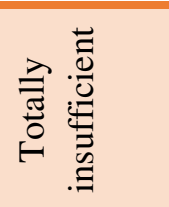 & 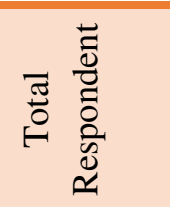 & \\
\hline Number & 0 & 0 & 12 & 20 & 18 & 50 & 2.24 \\
\hline Percentage & $0.0 \%$ & $0.0 \%$ & $24.0 \%$ & $40.0 \%$ & $36.0 \%$ & $100.0 \%$ & \\
\hline
\end{tabular}


Table 15: Decreased social barriers

\begin{tabular}{|c|c|c|c|c|c|c|c|}
\hline & \multicolumn{6}{|c|}{ Description of Respondents } & \multirow[b]{2}{*}{ 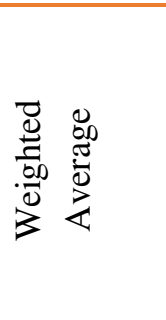 } \\
\hline & 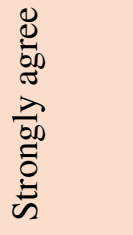 & $\begin{array}{l}\frac{8}{0} \\
\substack{0 \\
<}\end{array}$ & 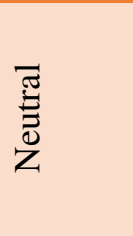 & 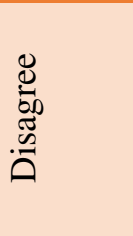 & 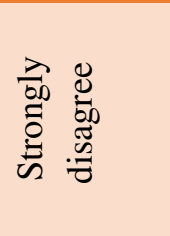 & 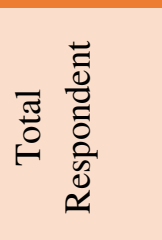 & \\
\hline Number & 18 & 14 & 0 & 10 & 8 & 50 & 3.48 \\
\hline Percentage & $36.0 \%$ & $28.0 \%$ & $0.0 \%$ & $20.0 \%$ & $16.0 \%$ & $100.0 \%$ & \\
\hline
\end{tabular}

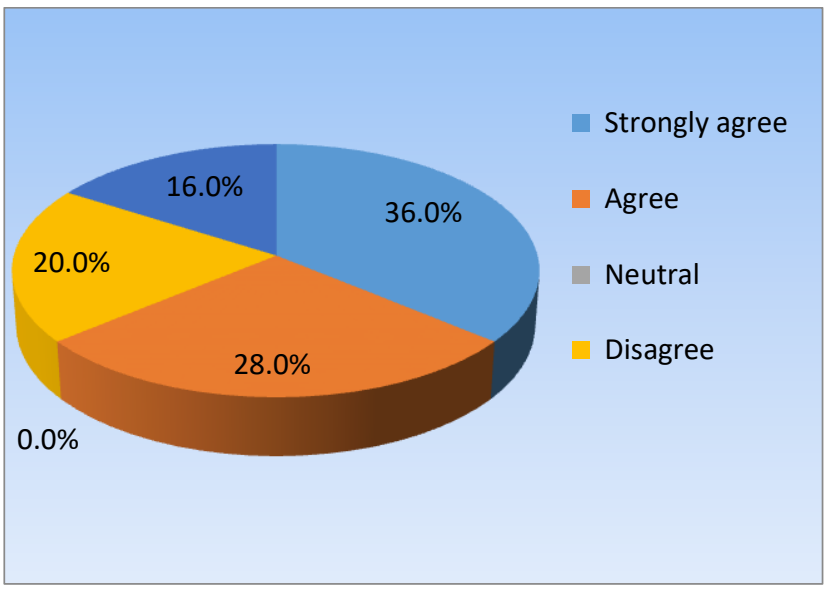

Fig 15: Decreased social barriers

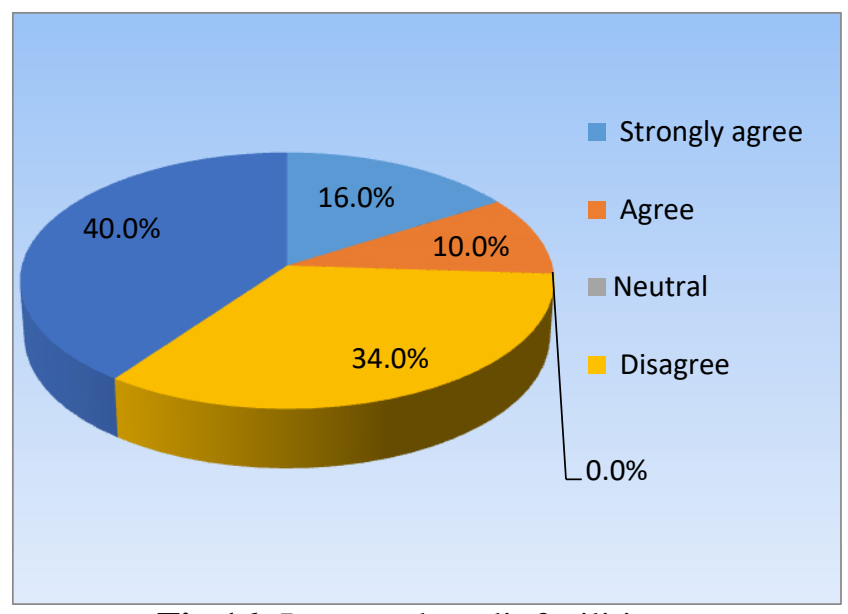

Fig 16: Increased credit facilities

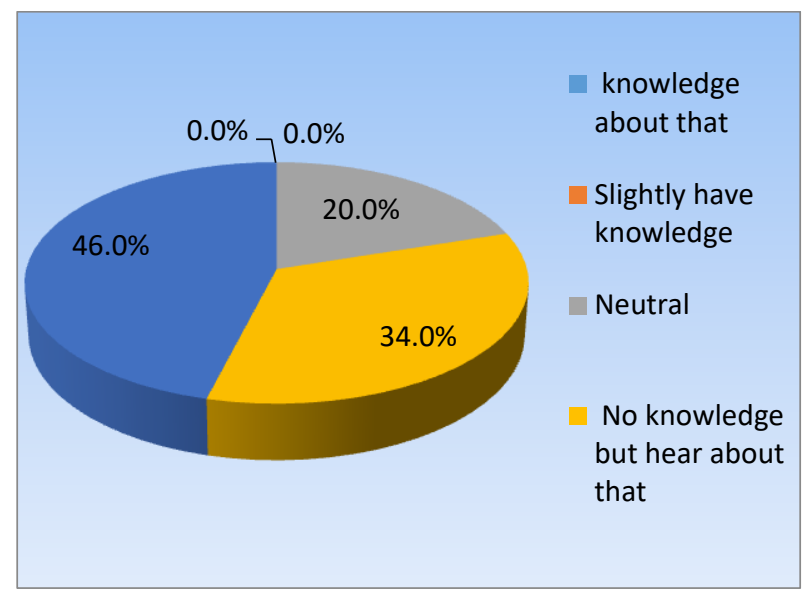

Fig 17: Sufficient financial facilities

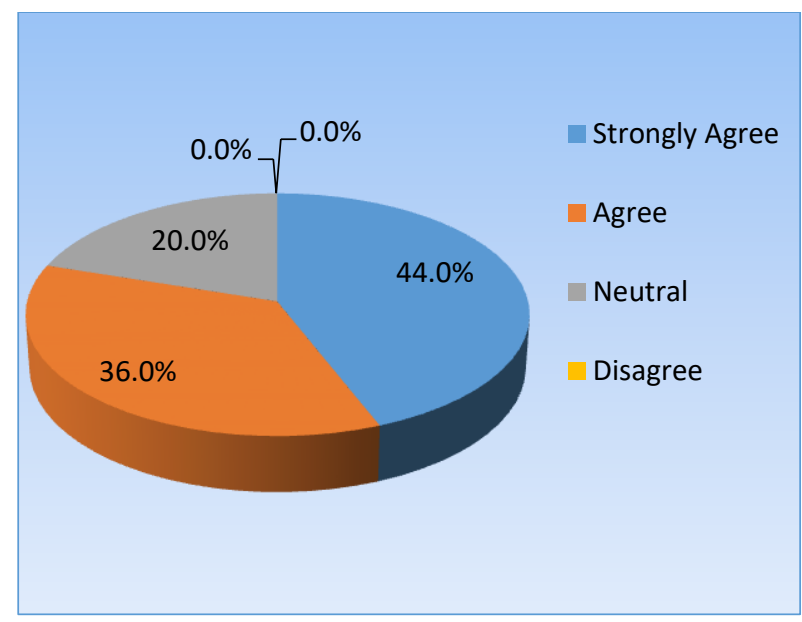

Fig 18: Helps in creating self dependency

Table 16: Increased credit facilities

\begin{tabular}{|c|c|c|c|c|c|c|c|}
\hline & \multicolumn{6}{|c|}{ Description of Respondents } & \multirow[b]{2}{*}{ 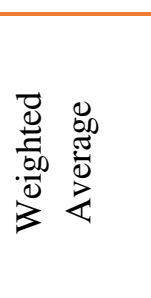 } \\
\hline & 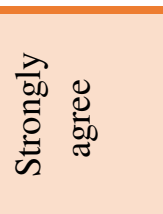 & 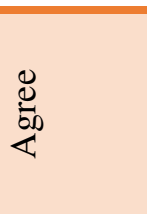 & 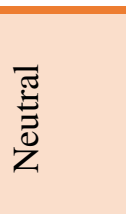 & 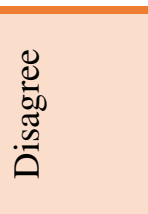 & 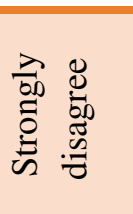 & 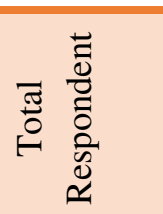 & \\
\hline Number & 8 & 5 & 0 & 17 & 20 & 50 & 2.28 \\
\hline Percentage & $16.0 \%$ & $10.0 \%$ & $0.0 \%$ & $34.0 \%$ & $40.0 \%$ & $100.0 \%$ & \\
\hline
\end{tabular}


Table 17: Sufficient financial facilities

\begin{tabular}{|c|c|c|c|c|c|c|c|}
\hline & \multicolumn{6}{|c|}{ Description of Respondents } & \multirow[b]{2}{*}{ 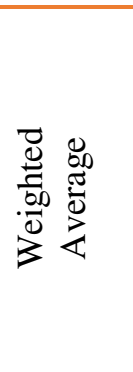 } \\
\hline & 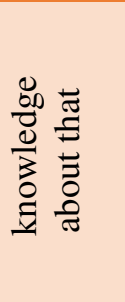 & 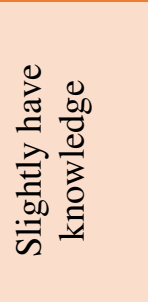 & 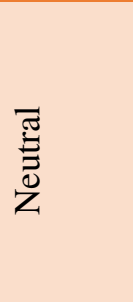 & 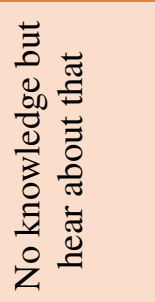 & 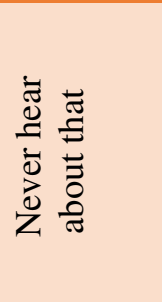 & 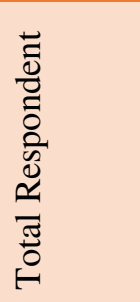 & \\
\hline Number & 0 & 0 & 10 & 17 & 23 & 50 & 1.74 \\
\hline Percentage & $0.0 \%$ & $0.0 \%$ & $20.0 \%$ & $34.0 \%$ & $46.0 \%$ & $100.0 \%$ & \\
\hline
\end{tabular}

Table 18: Helps in creating self dependency

\begin{tabular}{|c|c|c|c|c|c|c|c|}
\hline & \multicolumn{6}{|c|}{ Description of Respondents } & \multirow[b]{2}{*}{ 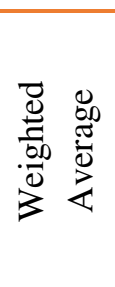 } \\
\hline & 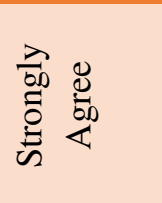 & 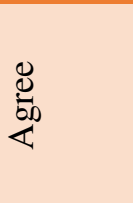 & 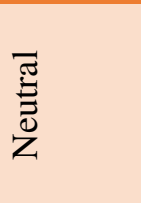 & 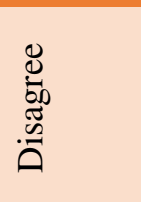 & 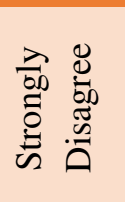 & 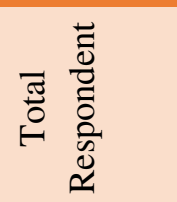 & \\
\hline Number & 22 & 18 & 10 & 0 & 0 & 50 & 4.24 \\
\hline Percentage & $44.0 \%$ & $36.0 \%$ & $20.0 \%$ & $0.0 \%$ & $0.0 \%$ & $100.0 \%$ & \\
\hline
\end{tabular}

\section{Major Findings of the study}

* Most women also have not received much inspiration from their family (spouse/parents) at this time. They encourage women to do business while their family is in a financial crisis.

* Most women feel that business makes them self-dependent.

* Women think that business helps in creating extra family income. Yet their percentage is less than half that. Since their overall income is spent on their families.

* It is noticed that women are now active in small and medium-sized businesses because they have no jobs. They are often illiterate, and often only have primary education. They need to support their families to raise additional revenue that they spend solely on their families.

* Most women spend all their earnings on their husbands, not on their own needs.

* For the most part, women said that trade licenses are very much required

\# But they can't get a trade license because they don't have experience of acquiring the trade license, and also because of certain irrecoverable circumstances.

* Most women said their starting (own) capital is not sufficient to indicate industry. They've got to find other sources of capital for that purpose.
Half of the women said that when they went to the bank to borrow money, the bankers' first experience was unsatisfactory. They assumed that the danger zone for recovering the money was for women entrepreneurs.

* It isn't easy to get loans from financial institutions, because the processes are too bureaucratic and the interest rate is too high.

* Many women are ignorant of financial institutions' facilities and often do not have complete knowledge of business planning, book keeping and accounting.

* They have no instruction from any organizations on business issues. There is just institutional instruction for some of them. And even now, there are different variables that obstruct women's business marketing.

* There is not enough government funding and no separate women's credit facilities. Although the government has declared a single-digit credit plan for women, it is not realistic in that regard.

* Since most women who join SME business are not educated, they have no knowledge of the modern technology that they can use for smooth running in their company.

* But it is a matter of joy that entering into small and medium-sized businesses transforms their way of life, eliminating their financial barriers. 


\section{Recommendation}

The accompanying measures ought to be taken to expand the women employment opportunity-

1. Banks should make the rundown of real and likely business people in both country and city zone. After the distinguishing proof, the help and supporting administrations must be stretched out to them for wanted developpment of provincial business.

2. Women business person ought to be given security free advance as they have no metal littlie resources. The edge of security ought to likewise be changed.

3. The methods of authorizing credit ought to be streamlined and advance application must be evaluated as ahead of schedule as could reasonably be expected.

4. The pace of enthusiasm for credits to working capital ought to be diminished and refund ought to be permitted to support opportune return of advance.

5. Bank credit strategy ought to be connected with modern approach of the nation. There ought to be an assignment of asset in the advance arrangement of banks to enhance the Government improvement plan and mechanical strategy. Coordination is additionally needed for appropriate allotment and conveyance of asset to country business visionaries.

6. Long term advance ought to be accessible.

7. A venture bank for women ought to be set up.

8. Women business person ought to have direct admittance to fund and other foundation and institutional offices.

9. Setting up an uncommon window with the Bangladesh Bank would work adequately and could resolve this issue.

10. Pre and post venture guiding for women business visionaries for credit ought to be conveyed.

11. Establishing credit ensure plot for women business people ought to be set up.

12. Preferential treatment of the women business visionaries ought to be diminished.

13. Trade License necessity and TIN testament strategy ought to be streamlined.
14. Export Promotion Bureau ought to be enacted to the point that it gets supportive for women business visionaries.

15. Government ought to build up a data place for women business person so they can get effectively the required data related with their business.

16. Establishing solid organization among various establishments and offices engaged with the advancement of the women as a rule and sharing their encounters.

17. Effective Training programs are required for women business visionaries' turn of events. The greater part of the women business people utilize customary manual preparing and abilities in their business. Innovation based preparing can assume a part in expanding efficiency, expanding the nature of yield and setting aside time and cash of women business visionary. Preparing ought to be given to women business people with the goal that they can utilize innovation successfully.

18. Women business visionary need to forwardthinking preparing for new items improvement, better administration of the endeavor and improving the nature of items and administrations.

19. Women business visionaries have small planning abilities; they need great and attractive planning preparing, which ought to be sorted out by government and others strong organizations.

20. Arrange administration expertise overhauling preparing for women business visionaries.

21. Provide consultancy administrations to the women business visionary to build up their business aptitude in a standard premise.

22. Supporting and guaranteeing the investment of the women business visionaries in public and global exchange fairs.

23. In Bangladesh, sex segregation is generally influenced, therefore even guardians gives more an incentive to the work and improvement to their child not to the advancement of little girl. Here, the social mindfulness program can be killed this separation.

24. Inheritance law of the nation ought to be improved so women approach assets and insurance for credit. 
25. Government and other nearby organization should make move to diminish the social obliges like different traditions identified with women life structure, strict limitations, eve-prodding and family tormenting.

26. Government ought to guarantee the made sure about climate for women business person and for entire female.

\section{CONCLUSION:}

Business assumes an imperative part in financial turn of events and modern development of a nation. Though the almost half of absolute populace is female, so it is clearly important to build up the women enterprise for the accomplishment of financial improvement of the country (Alauddin and Chowdhury, 2015). Bangladesh is in such position and the development of women business enterprise has risen enormously for some couple of years. Here the SME is assuming an essential function to be improvement of the business enterprise. In spite of the fact that the women business person face numerous issues as money related or credit office, bank advance, preparing office, advertising issues, federal retirement aide issue and disposition toward women of their family and society is likewise make issues to create themselves as entrepreneur. Our government has embraced a few strategies with respect to women enterprise improvement however because of managerial entanglement every one of these approaches may fizzle at the hour of suggestion. Some others semi-self-ruling association and NGOs are working for women enterprise advancement in Bangladesh by giving preparing office and others strong business and showcasing office. Be that as it may, the SME credit, monetary variables and different business method generally related with administrative body and their suggestion strategy. In Bangladesh, presently women are instructed and intriguing about set up their own business as per the examination. So subsequently, the all-encompassing SME program can encourage them by giving insurance free and simple access of financing their business. So here the administrations rules, strategies with respect to business set up and bank related guideline ought to be receive adequately and rules and strategy development ought to consistently uphold the women business visionary. So the women business person can create themselves and could be performing to the advancement of nation's manageable financial development just as make commitment for their family and present day society.

\section{ACKNOWLEDGEMENT:}

The study has been done with the support of the author solely of this paper and there was no financial support from any institution to conduct the research work.

\section{CONFLICT OF INTERESTS:}

The author declares there is no conflict of interest.

\section{REFERENCES:}

1. Ahammad, I. (2013). Women Entrepreneurship Development in Bangladesh: Challenges and Prospects, International Journal of Innovative Research and development, 2(7). Pp. 41-48.

http://citeseerx.ist.psu.edu/viewdoc/download? $\underline{\text { doi }=10.1 \cdot 1.1010 .8423 \& \text { rep }=\text { rep } 1 \& \text { type }=p d f}$

2. Ahmed, M. U., Mannan, M. A., Razzaque, A.and Sinha, A. (2004). 'Taking Stock and Charting a Path for SMEs in Bangladesh' Bangladesh Enterprise Institute, Dhaka.

3. Alauddin, M. and Chowdhury, M. M. (2015). Small and Medium Enterprise in Bangladesh-Prospects and Challenges, Global Journal of Management and Business Research: Finance, 15(7); Pp. 1-11.

https://www.researchgate.net/publication/3357 95524

4. Al-Hossienie, C. A. (2011). Socio-Economic Impact of Women Entrepreneurship in Sylhet. Bangladesh Development Research Center (BDRC).Pp. 1-25. https://ideas.repec.org/p/bnr/wpaper/12.html

5. Bangladesh Bank, BB, (2008). A Note on the Contribution of Small and Medium Enterprises to GDP in Bangladesh, Bangladesh Bank. Pp. 1-18.

https://www.bb.org.bd/pub/research/policypap er/pp0806.pdf

6. Basu S, Roy A, and Karmokar S. (2020). Effectiveness of microfinance on household income generation strategy in the southwest region of Bangladesh, Asian J. Soc. Sci. Leg. Stud., 2(3), 56-62.

https://doi.org/10.34104/ajssls.020.056062

7. Bosri, R. (2016). SME Financing Practices in Bangladesh: Scenario and Challenges 
Evaluation, World Journal of Social Sciences, 6(2), Pp. 39-50.

https://zantworldpress.com/wp-content/uploa ds/2020/01/4.-Rabaya.pdf

8. Chowdhury, S. A.; Azam, K. G. and Islam, S. (2012). Problems and Prospects of SME Financing in Bangladesh, Asian Business Review, 2(2); 109-116. https://doi.org/10.18034/abr.v2i2.111

9. Financial Express, (2020). Dhaka moves to amend labour law for retaining EU GSP. http://www.thefinancialexpress-bd.com

10. Hasan, R.A. and Islam, K.M.Z. (2008). Bridging the Gap between Microfinance and SME financing in Bangladesh: Unlocking the potentials. Daffodil International University Journal of Business and Economics, 3(1), 1-17.

11. Islam MJ. (2020). Factors influencing family size: a critical study on Khulna district of Bangladesh, Br. J. Arts Humanit., 2(4), 7381. https://doi.org/10.34104/bjah.020073081

12. Khatun, F. and Kabir, F. (2013). Women SME Entrepreneurs in ensuring women empowerment in Bangladesh: A Study on Women SME Entrepreneurs in Bangladesh, American International Journal of Research in Humanities, Arts and Social Sciences. 5(1), 61-68.

http://iasir.net/AIJRHASSpapers/AIJRHASS1 4-134.pdf

13. Rabbani, M., \& Sulaiman, M. (2005). 'Financing SMEs and its Effect on Employment
Generation: A Study of BRAC Bank's SME Lending', Dhaka Bank Research and Evaluation Division. 23: 1-15.

http://dspace.bracu.ac.bd/xmlui/handle/10361/ 13186

14. Rahman and Mahmood, (2007). Potential of Small and Medium Enterprises, PSME, (2015). 11 March 2015, the Daily Star. SME Foundation, Web Portal.

https://www.thedailystar.net/supplements/24th -anniversary-the-daily-star-part-2/potentialsmall-and-medium-enterprises-70927

15. Rashid MH and Islam MA. (2020). Impacts of unemployment on graduates in Bangladesh: a case study, Br. J. Arts Humanit., 2(5), 87-94. https://doi.org/10.34104/bjah.020087094

16. Sultana, A. (2012). Promoting Women's Entrepreneurship through SME: Growth and Development in the context of Bangladesh, IOSR Journal of Business and Management, 4(1), Pp. 18-29. https://doi.org/10.9790/487X-0411829

17. Yasmin T., and Husna CA. (2020). Familial support as a determinant of women career development: a qualitative study, Asian J. Soc. Sci. Leg. Stud., 2(4), 76-87. https://doi.org/10.34104/ajssls.020.076087

18. Zaman, S. (2013). Women in Business: A Study on the Development of Women Entrepreneurship in Bangladesh, World Journal of Social Sciences, 3(6), Pp. 175188. 